\title{
挨拶 一日本の歴史と対外関係一
}

日本学士院会員 東 野 治 之

「近世東アジアに扔ける宗教・通商・国際関係」と題するこのセッションは、日 本学士院の会員 2 名と、国際学士院連合で承認された事業を委嘱してきた東京大学 史料編纂所関係の 2 名の教授による発表で構成される。対象は、主に 17 世紀初めか ら19世紀半ばに至る約250年間であり、その前後を含め日本の経済や社会がどのよ うな特質を持ち、外交、宗教においていかに外国と関わってきたかを明らかにする ことを目的とする。

一体、日本学士院と国際学士院連合（UAI）との関係は1919年に始まるが、その 直後から、日本学士院は関係国の理解と協力のもと、主としてヨーロッパ諸国に散 在する日本関係史料の収集を目指し、それは国際学士院連合の第 7 委員会の事業と して進められてきた。この事業は、第 2 次世界大戦によって一時期中断されたが、 その後再開され、現在は具体的進行を東京大学史料編纂所に委嘱し、在オランダ史 料を中心に、収集、翻訳、出版が継続中である。今回の五野井、松井両教授による 発表は、この事業の成果を反映したものに他ならない。

さて、このセッションが対象とする時代は、日本の西洋化が始まる前の 250 年で あるが、日本はそれ以前、本州北部から九州に至る地域を中心に、長い歴史を重ね てきた。その歴史に見られる大きな特徵は、自立性である。日本は旧世界の東端に 位置していたこともあって、歴史時代に入ってからは、中国・朝鮮との交流は続い たものの、自立性の強い文化を形成してきた。1300年余り一貫した国号「日本」を 使用してきたこと、3 世紀末以来、同一系統の言語を使用してきたことは、この特 徵を表す恰好の例証である。

即ち日本 (太陽が昇るところ) という国号は、中華の東端に位置する意味を持ち、 701年に対外的な自称として中国王朝に認められ、以後基本的に国号として機能し てきた。「日本」の古い漢字音が長期間にわたりジャパンとして、世界に通用して いるのも理由のないことではない。

また日本語が 3 世紀にまで遡ることは、中国の正史に書きとめられたいくつかの 単語が、日本語の古語として、発音上も意味上も理解できることから明らかである。 その単語のひとつヤマトが、今日に至るまで、漢字による国号日本に対し、固有言 語による国号として生き残っている事実は、日本語の一貫性を物語る象徴的な事例 
である。このような自立的性格の一端は、外国勢力の大規模な侵入が、13世紀に起 きたモンゴルの襲来しかないことにも表れている。

こうした事情の下、日本の歴史研究では、徳川時代は、一旦西欧文明に目を向け た日本が、これを拒んで「鎖国」した時代とされてきた。近年、この見方は修正さ れ、海外との交流を絶ったかに見えるこの時代も、4 か所で交流が維持されたこと を評価するのが一般的となっている。しかしそれにも拘らず、交流が中央から遠く 離れたわずか 4 か所に限られ、人的な交流が厳しく規制されていたことを見逃すこ とはできず、やはり日本の自立性こそ注目すべきであろう。このセッションを機に、 ここに集まった方々が、日本の歴史の特色と、日本の西洋化が準備されたこの興味 深い時代について認識を深め、現在の日本を知る一助としていただくよう希望する。 